\title{
Pulmonary Function Tests in Two Wheeler Drivers Travelling on Pune Banglore National Highway (NH4) India
}

\author{
Mr. Satyajeet Patil ${ }^{1}$, Dr. Shrirang Patil ${ }^{2}$ \\ ${ }^{I}$ II Year M B. B.S. Student, Krishna Institute of Medical Sciences Deemed University, Karad, Maharashtra, \\ India) \\ ${ }^{2}$ (Department of Physiology, Krishna Institute of Medical Sciences Deemed University, Karad, Maharashtra, \\ India)
}

\begin{abstract}
Pulmonary function tests were studied in two wheeler drivers daily travelling on national highway 4(NH4). 50 drivers were included in study after applying exclusion criteria. Control group (50) of age matched healthy paramedical workers from KIMS, University was included. Approval from Institutional Ethical Committee was obtained. Informed written consent was taken from each participant. Spirometric lung function test were carried out in department of Physiology at KIMSU, Karad. Pulmonary function parameters included were FVC (Forced Vital Capacity), FEV1 (Forced Expiratory Volume in First second of FVC), FEV1\% (FEVI as \% of FVC), PEFR (Peak Expiratory Flow Rate in liters/sec), FEF25-75\% (Forced Expiratory Flow Rate during 25 to $75 \%$ of expiration), FEF 0.2-1.2 (Forced Expiratory Flow between 0.2 -1.2 liters of expiration) and MVV (Maximum Voluntary Ventilation). After computing mean and SD of each parameter group comparison was done. Impairment of lung function (Mixed type i. e restrictive \& obstructive) was found in the study group compared to control group. The impairment was more after long term exposure. Protective measures like use of face mask and periodical health check up was advised.
\end{abstract}

Key Words: Highway Pollution, Spirometric, Lung Function, Two Wheeler Drivers

\section{Introduction}

In almost all the countries of the world air pollution due to motor vehicles is becoming the major problem of physical health of the people. The developed countries having about $86 \%$ of the world's vehicle have long standing and extensive experience of the problem. Rapid industrial growth, increase in population and improved standards of living has also created the similar problem in developing countries. Motor vehicles are the major source of the air pollution. The air contains several toxic pollutants, mainly sulphur oxides (Sox), nitrogen oxides (NOx) and dust with a diameter of less than 10 um (particulate matter PM 10)[1,2,3,4].Each of these cause air flow limitation and increase in prevalence of bronchial hyper reactivity and airways infections. Moreover, it intensifies the symptoms of existing allergic diseases (asthma) additionally stimulating the reconstruction of lung tissue and causing its structural changes [5,6,7]. The influence of air pollution on pulmonary function has been known for a long time. Various studies have done for assessing respiratory health status of individuals exposed to air pollutants by recording different PFT (Pulmonary function test) parameters $[8,9,10]$.Spirometry being non-invasive technique and simplest procedure is being widely used for assessment of lung function. Ogunsola $\mathrm{J}$ et al found significant difference in Peak expiratory flow rate (PEFR), Forced vital capacity (FVC) and Forced expiratory flow in one second (FEV1) between Nigerian traffic wardens and control subjects [11]. Lubinski $\mathrm{W}$ et al found significant air flow limitation in healthy young men from different regions of Poland [12]. Pal P et al recorded significant decrease in various PFT parameters in traffic police personnel compared to control group [13]. Other studies also noticed similar findings in taxi drivers [14] and in young men [15]. There is no information about effects of highway air pollution on two wheeler driver's lung function tests. They are travelling on highway (without protective measures) which is having dense traffic of heavy vehicles on diesel round the clock. Some lung function derangement is expected. So the present study is planned.

Researchers from various parts of the world have been studying the effects of highway air pollution due to vehicles, on health of people. A 2000 Denver study showed that children living very close to highways (within 250 yards) are six times more likely to develop all types of cancer and eight times more likely to get leukemia [16]. Recent study showed that day-to-day exposure to soot or fine particulate matter increased risk of lung cancer deaths [17]. There was increased rate of hospitalization for asthma in children living in neighborhood of roads with heavy truck traffic [18].It was observed that there was increase in the risk of premature birth and low birth weight for infants born to women living near high traffic areas in Los Angeles Country [19].It was found that the number of ultra-fine particles in the air was approximately 25 times more concentrated near the highways and the pollution levels gradually decrease back to normal levels, around 300 meters, or 350 yards, downwind from the highway. It was also found that motor vehicles are the most significant sources of ultra-fine particles, which have been linked to increased mortality and morbidity. Ultra-fine soot 
particles are more toxic than larger particles with the same chemical composition. Moreover the researchers found higher concentration of carbon monoxide pollution near the highways [20]. Dutch researchers found that people living near a main road were almost twice as likely do die from heart or lung disease and 1.4 times as likely to die from any premature cause compared with those who lived in less traffic areas [21].In BadenWurttemberg, Germany it was reported that there were five times more deaths due to motor vehicle pollution than from traffic accidents [22]. In a study done in Patiala (India), a significant decline in lung function of traffic policeman was found compared to controls [23]. World Health Organization (WHO) has mentioned in its report on motor vehicle air pollution (WHO/EOS/97.08), that motor vehicle air pollution can have serious adverse health effects on the population. These problems are likely to be particularly acute in the rapidly growing cities of the developing world if uncontrolled growth of the vehicle fleet is allowed to take place. This report says planning must begin to provide alternatives to the motor vehicle fleet and to reduce emissions of the vehicle fleets that the growing populations will demand. It also expects that administrators who are responsible for air quality management planning, to develop appropriate control strategies. This would help to achieve a state of sustainable development that does not adversely affect the health of the people.

\section{Material \& Methods}

The study was conducted in Department of Physiology at Krishna Institute of Medical Sciences University, Karad. Permission from Institutional Ethical Committee was taken before start of the study. The subjects $(\mathrm{N}=50)$ were male workers in Krishna Institute of Medical Sciences, Karad, who were daily travelling on NH4 highway (for distance of $\min 10 \mathrm{~km}$ ) by use of two wheelers. The workers having history of previous lung or major heart disease were excluded. Smokers were also excluded. Selected subjects were divided into groups depending upon duration of exposure as D1-D5 (D1-from 0 to 2year, D2-from 2 to 5 year, D3-from 5 to 10 year, D4-from 10 to 15 year and D5 -more than 15years). A control group of 50 age matched healthy male workers from Medical College, who are not travelling daily on highway, was taken for comparison. All the subjects were called in department for the study of lung function tests. Informed written consent from all the subjects (including controls) was taken. A detail history was taken, including record of anthropometric measurements i.e. height and weight, duration of exposure to highway air pollution, present respiratory symptoms if any, past history of any respiratory/cardiac disease. Clinical examination was done to rule out any existing pulmonary disease. Subjects having smoking habits, past history of chronic respiratory or cardiac disease, having examination findings of any respiratory or cardiac disease were excluded from study.

Lung functions were measured by using a computerized "MEDSPIROR" (RMS Chandigarh, India) instrument. Spirometry was carried out as per guidelines of American Thoracic Society [24]. Before recording lung functions, subjects were shown a demonstration of the test. Consequently a minimum three readings of each test were taken for every subject and the best of the three was selected for having reproducibility and validity of the recorded parameters. The lung function parameters included were FVC (Forced Vital Capacity), FEV1 (Forced Expiratory Volume in First second of FVC), FEV1\% (FEV1 as \% of FVC), PEFR (Peak Expiratory Flow Rate in liters/sec), FEF25-75\% (Forced Expiratory Flow Rate during 25 to $75 \%$ of expiration, FEF 0.2-1.2 (Forced Expiratory Flow between 0.2 -1.2 liters of expiration) and MVV (Maximum Voluntary Ventilation).The values of all tests were taken as percent of predicted as per age, gender and height of each subject according to standard equations [25] as follows:

For males ( $>18$ years):

(1) FVC (L) $=0.050 \times$ height $(\mathrm{cm})-0.014 \times$ age $(\mathrm{yrs})-4.49$

(2) FEV1 (L) $=0.040 \times$ height $(\mathrm{cm})-0.021 \times$ age $(\mathrm{yrs})-3.13$

(3) PEFR $(\mathrm{L} / \mathrm{Sec})=0.071 \mathrm{x}$ height $(\mathrm{cm})-0.035 \mathrm{x}$ age $(\mathrm{yrs})-1.82$

(4) $\operatorname{MVV}(\mathrm{L} / \mathrm{min})=1.92 \times$ height $(\mathrm{cm})-0.816 \times$ age $(\mathrm{yrs})-37.0$

(5) FEF25-75(L/Sec) $=0.019 x$ height $(\mathrm{cm})-0.045 \mathrm{x}$ age $(\mathrm{yrs})+2.51$

(6) FEF.2-1.2 $(\mathrm{L} / \mathrm{Sec})=0.051 \mathrm{x}$ height $(\mathrm{cm})-0.068 \mathrm{x}$ age $(\mathrm{yrs})+0.94$

Statistical analysis was carried out after summarizing the data by computing mean and standard deviation (SD) of each study variable. The significance of difference of each variable between study and Control groups was studied applying student $\mathrm{t}$ test.

\section{Results}

After applying student $t$ test it was found that study group (Direct exposure group) and control group were age matched $(\mathrm{t}=0.3035, \mathrm{p}>0.05)$. Anthropometric measurements are shown in table 1 . 
Table1: Anthropometric measurements

\begin{tabular}{|l|l|l|l|}
\hline Group & $\begin{array}{l}\text { Age in years } \\
\text { Mean } \pm \text { SD }\end{array}$ & $\begin{array}{l}\text { Height in cms } \\
\text { Mean } \pm \text { SD }\end{array}$ & $\begin{array}{l}\text { Weight in Kg } \\
\text { Mean } \pm \text { SD }\end{array}$ \\
\hline Study group(50) & $41.44 \pm 10.25^{\text {ns }}$ & $167.26 \pm 6.16$ & $66.22 \pm 9.57$ \\
Control group(50) & $40.8 \pm 10.82$ & $60.62 \pm 9.51$ \\
\hline
\end{tabular}

ns, no significant difference compared to control

Results of various spirometric lung function test parameters are shown in table 2.

Table 2: Mean \pm SD of Lung function parameters in study group and in control group

\begin{tabular}{|l|l|l|l|l|}
\hline Lung parameter & $\begin{array}{l}\text { Study group } \\
\text { (50) } \\
\text { \% of predicted }\end{array}$ & $\begin{array}{l}\text { Control group } \\
(50) \\
\% \text { of predicted }\end{array}$ & F value & P value \\
\hline FVC & $68.32 \pm 14.92$ & $84.46 \pm 15.60$ & 5.285 & $<0.0001$ \\
FEV1 & $78.20 \pm 14.84$ & $95.04 \pm 17.97$ & 5.108 & $<0.0001$ \\
FEV1/FVC \% & $112.26 \pm 10.47$ & $111.28 \pm 7.89$ & 0.5285 & 0.59 \\
FEF25-75 & $72.46 \pm 21.04$ & $82.78 \pm 25.54$ & 2.205 & 0.02 \\
FEF .2-1.2 & $60.34 \pm 21.17$ & $78.40 \pm 23.31$ & 4.055 & $<.0001$ \\
PEFR & $62.96 \pm 17.82$ & $78.94 \pm 17.95$ & 4.466 & $<0.0001$ \\
MVV & $67.14 \pm 16.68$ & $83.80 \pm 15.88$ & 5.114 & $<0.0001$ \\
\hline
\end{tabular}

FVC (Forced Vital Capacity); FEV1 (Forced Expiratory Volume in First second of FVC); FEV1\% (FEV1 as \% of FVC); PEFR (Peak Expiratory Flow Rate in liters/sec); FEF25-75\% (Forced Expiratory Flow Rate during 25 to $75 \%$ of expiration); FEF 0.2-1.2 (Forced Expiratory Flow between 0.2 -1.2 liters of expiration) and MVV (Maximum Voluntary Ventilation).

The FVC was less in direct group compared to that in control group, and this difference was not statistically significant $(\mathrm{p}<0.0001)$. There was reduction in value of FEV1 in study group than in control one, the difference was significant ( $\mathrm{p}<0.0001$ ). There was no significant difference in FEV1/FVC \% in the groups. There was reduction in FEF25-75 in subjects compared to controls and this difference was also statistically significant $(\mathrm{P}<0.05)$.FEF.2-1.2 was significantly reduced in study group compared to that of control group $(\mathrm{P}=0.0001)$. There was also significant reduction in MVV in the study group compared to control group $(\mathrm{p}<0.0001)$. PEFR was significantly reduced in study group compared to control group $(p<0.0001)$. Mean values of various lung function parameters in study exposure group, as per duration of exposure of subjects to highway pollution are shown in table 3.

Table 3: Mean \pm SD of Lung function parameters in direct exposure group according to duration of exposure

\begin{tabular}{|c|c|c|c|c|c|}
\hline Lung function & D1 (14) & D2 (11) & D3 (7) & D4 (5) & D5 (13) \\
\hline & $\begin{array}{l}\text { Mean } \pm \text { SD } \\
\% \text { of Predicted }\end{array}$ & $\begin{array}{l}\text { Mean } \pm \text { SD } \\
\% \text { of Predicted }\end{array}$ & $\begin{array}{l}\text { Mean } \pm \text { SD } \\
\% \text { of Predicted }\end{array}$ & $\begin{array}{l}\text { Mean } \pm \text { SD } \\
\% \text { of Predicted }\end{array}$ & $\begin{array}{l}\text { Mean } \pm \text { SD } \\
\% \text { of Predicted }\end{array}$ \\
\hline FVC & $70.57 \pm 7.33$ & $62.09 \pm 22.02$ & $70.42 \pm 6.18$ & $73 \pm 9.46$ & $68.23 \pm 18.57$ \\
\hline FEV1 & $78.71 \pm 7.88$ & $77.81 \pm 17.66$ & $78 \pm 6.95$ & $70.4 \pm 9.20$ & $81.07 \pm 22.02$ \\
\hline FEV1/FVC $\%$ & $111.57 \pm 6.30$ & $111.54 \pm 10.16$ & $110.85 \pm 8.13$ & $100.6 \pm 17.53$ & $118.84 \pm 8.78$ \\
\hline FEF25-75 & $74.57 \pm 18.70$ & $71.27 \pm 18.89$ & $68.85 \pm 15.87$ & $60 \pm 21.22$ & $77.92 \pm 27.29$ \\
\hline
\end{tabular}




\begin{tabular}{|l|l|l|l|l|l|}
\hline FEF.2-1.2 & $65.57 \pm 16.04$ & $61 \pm 23.50$ & $59.85 \pm 14.64$ & $51.60 \pm 21.25$ & $57.76 \pm 27.60$ \\
PEFR & $65.21 \pm 12.69$ & $62.72 \pm 19.27$ & $61.57 \pm 15.25$ & $65.2 \pm 22.33$ & $60.61 \pm 22.69$ \\
MVV & $66.71 \pm 11.67$ & $69.9 \pm 21.42$ & $66 \pm 13.46$ & $62.4 \pm 20.14$ & $67.69 \pm 19.05$ \\
\hline
\end{tabular}

D1,0-2 years; D2,2-5 years; D3,5-10 years; D4, 10-15 years; D5, > 15 years

There was reduction in values of FVC, FEV1, FEF25-75, FEF.2-1.2 and PEFR as the duration of exposure was more. But there was no consistent relationship was found between values of FEV1/FVC \% and MVV and the duration of exposure.

\section{Discussion}

The main function of lung is to maintain the partial pressures of oxygen and carbon dioxide within normal limits. The principle mechanisms involved in achieving this goal are ventilation, diffusion and perfusion. The computerized spirometry is widely used by clinics to assess the ventilation function of the lung [26].This is very simple procedure and can be carried out even as a bedside investigation with portable instrument. Various studies have carried out in India as well as outside India to evaluate the effects of air pollution of roads on healthy young men [12], traffic police [13,23], three wheeler diesel taxi drivers [14], healthy nonsmoker young men. But probably no study has been carried out for evaluation of lung function of two wheeler drivers daily travelling on highways. So the present study was carried out. Statistical analysis revealed that subjects in study groups and in control groups were age matched. In this study there was significant reduction in FVC and MVV of study group compared to control group. This is indicative of some kind of restriction to expansion of lungs. The changes might be in the tissues of lungs due to chronic irritation by pollutants.FEV1 is the amount of air expired in first second of forced vital capacity (FVC). PEFR is the maximum rate of flow during expiration. FEV1 and PEFR were significantly reduced in study group compared to controls. These two parameters are indicative of the capacity of the expiratory muscles. This suggests some obstruction during expiration.FEF25-75 indicate the condition of smaller airways and FEF.2-1.2 indicate the condition of larger airways. In our study, both the parameters were significantly reduced in two wheeler drivers compared to those with control. This also indicates obstructive type of lung dysfunction. Similar findings were observed in traffic policemen in studies from India $[13,23]$. Another study related to exposure to automobile exhaust in a diesel bus garage and roads has reported almost similar type of findings [27].The manures like FVC, PEFR and MVV requires more force generation, reduction of their values in two wheeler drivers might suggest reduction in lung compliance over the years of exposure, that goes in favor of restrictive type of lung dysfunction. These findings overall suggest a mixed type of lung disorder i.e. restrictive and obstructive. FEV1/FVC\% is better indicator of the condition of bronchial musculature. In the present study we did not found any difference between two groups. The reason might be due to more reduction in values of FVC than that of FEV1 in study group. A more detailed study considering larger sample size may through a more light on this.

\section{Conclusions}

We noticed progressive decline (in relation to duration of exposure) in lung function of two wheeler drivers travelling on national highway (NH4). As most of them are likely to be asymptomatic till significant lung damage occurs, periodic health check up of the workers was advised. Protective measures such as use of face mask may protect from further dysfunction or prevent from the development of lung dysfunction in those people who are likely to be exposed. Two wheeler drivers were informed about this. A large scale study is necessary to through a more light on this important topic.

\section{Acknowledgements}

We are thankful to ICMR (Indian Council of Medical Research) for allowing us to complete this research project as a short term student research ship (STS 2013). We are also thankful to the Management and Principal of Krishna Institute of Medical Sciences deemed University allowing us to utilize the infrastructure in the Institution. We also thank the head of Department of physiology and the staff for their kind support and help for completion of the research project. We also thank the participants of study for their cooperation.

\section{References}

[1] Panstwowa Inspekceja Ochrony Srodowiska.Mitosek G (Ed): Raport o stezeniu zanieczyszczeri rokupowietrza w Polsce w 1996 roku na podstawie pomiarow w sieci podstawowej. Biblioteka Monitoringu Srodowwiska. Warszawa1997.

[2] Pansiwowa Inspekceja Ochrony Srodowiska. Panstwowa Inspekeja Sanitarna. Zanieczyszczenia powietrza w Polsce w 1993,1995, 1996-1997 roku. Biblioteka Monitoringu Srodowiska, Warszawa 1994, 1997, 1998.

[3] Roemer W, Hoek G, Brunekreef B, Haluska J, Kalandidi A, Pekkanen J: Daily variations in air pollution and respiratory health in a multicentre study: the PEACRE project .Pollution effects on Asthmatic Children in Europe. Eur Respir J 1998, 12(6), 1354-1361.

[4] Rusznak C, Devalia JL, Davies RJ: The impact of air pollution on allergic disease. Allergy 1994, 49, $21-27$. 
[5] Atkinson RW, Anderson HR, Strachan DP, Bland JM, Bremner SA, Ponce de Leon A: Short-term associations between outdoor air pollution and visits to accident and emergency departments in London for respiratory complaints. Eur Respir J 1999, 13,257-265.

[6] van der Lende R, Kok TJ, Reig RP, Quanjer PH, Schouten JP, Orie NG: Decrease in VC and FEV1 with time : indicators for effects of smoking and air pollution. Bull Eur Physiopathol Respir 1981, 17(5), 775-792.

[7] Veigi G: Air pollution epidemiology and the European Respiratory Society: the PEACE project. Editorial Eur Respir Rev 1998, 8 (52), 1-3.

[8] Valic F, Beritie-Stahujak D, Yousefy I, Butovic D, Gregoric J. Inflence of traffic air pollution on the carboxyhemoglobin level and ventilatory function of the lung. Acta Med lugosl 1973; 27: 465-478.

[9] Reichei G, Wobith F, Ulmer WT. Acute and chronic effects of air pollution produced by traffic at a busy crossing on lung function in humans. Determination of CO,Hb, and Pb in blood. Int Arch Arbeilsmed 1970; 26: 84-97.

[10] De Bruin A, Vroege D, Van Haeringen. Study of carbon monoxide uptake in traffic policemen. Tijdschr Soc Geneeskd 1965; 43: $146-151$.

[11] Ogunsola OJ, Oluwole AF, Asubiojo OI, Dursinmi MA, Fatusi AO, Ruck W. Environmental impact of vehicular traffic in Nigeria; health aspects. Sci Total Environ 1994; 111-116.

[12] Lubinski W, Toczyska I, Chcialowski A, Plusa T. Influence of air pollution on pulmonary function in healthy young men from different regions of Poland. Ann agric Environ Med 2005;12: 1-4.

[13] Pal P, John RA, Dutta TK, Pal GK. Pulmonary function test in traffic police personnel in Pondicherry. Indian J Physiol Pharmacol 2010; 54(4): 329-336.

[14] Binawara BK, Gahlot S, Mathur CM, Kakwar A, Gupta R, Rajnee. Pulmonary function tests in three wheeler diesel taxi drivers in Bikaner city. Pak j Physiol.2010;6(1): 28-31.

[15] Kumar A, Verma SK, Bhargava V. Impact of chronic air pollution exposure on pulmonary function in healthy nonsmoker young men from two different areas of Kanpur city. Natl J Physiol Pharm Pharmacol 2012; 2: 128-133.

[16] Peatson,Wachtel, Robert L, Peatson, and KristeEbie. Distance weighted traffic density in proximity to a home is a risk factor for leukemia and other childhood cancers. Journal of Air and Waste Management Association.2000;50:175-180.

[17] Pope, Clive Arden III, Richard P. Burnett, et,al. Lung cancer, Cardiopulmonary mortality, and Long term Exposure to Fine Particulate Air Pollution. Journal of the American Medical Association.2002; Vol.28, No.92.

[18] Lin, Shao, Jean Pierre Munsie, Syni- An Hwang, Edward Fitzgerald and Michael R. Cayo. Childhood Asthma Hospitalization and Residential Exposure to State Route Traffic. Environmental Research Section.2002; Vol.88:73-81.

[19] Wilhelm, Michelle and Beate Ritz. Residential Proximity to Traffic and Adverse Birth Outcomes in Los Angeles Country, California,1994-1996. Environmental Health Perspectives doc.10.1289/chp.5688.

[20] Zhu, Yilang, William C,Hinds, Kim Seongheon, Si Shen, Constantinos Sioutas. Concentrationand size distribution of ultra -fine particles near a major highway. Journal of the Air and Waste Management Association,September 2002.And, Study of ultra-fine particles near a major highway with heavy-duty diesel traffic. Atmospheric Environment.2002; 36:4323-4335.

[21] Hock, Brunekteef, Goldbohn, Fischer, van den Brandt. Association Between Mortality and Indicators of Traffic-related Air Pollution in the Netherlands. A Cohort Study. Lancet.2002; 360(934):1203-9.

[22] Szagun and Seidel. Mortality due to road traffic in Baden-Aurttemberg. Gesundheitswesen 2000; 62(4): $225-33$.

[23] Gupta S., Mittal S.,Kumar A. and Singh KM. Respiratory effects of air pollutants among nonsmoking traffic policemen of Patiala, India. Lung India. 2011; 28(4): 253-257.

[24] Miller MR, Hankinson J, Brusasco V et al.Series "ATS / ERS Task Force: Standardization of lung function testing" Eur Respir J $2005 ; 26: 319-338$.

[25] Kamat SR. Recorders Operation manual for Spirometry (RMS Recorder and Medicare systems, Chandigarh) 2002 ; C: 1-9.

[26] Virani N, Shah B, Celly A. Pulmonary function studies in healthy non-smoking adults in Sri Aurobindo Ashram, Pondichery. Ind J Med Res 2001; 114:177-184 